\title{
EFEKTIFITAS KOMBINASI PIJAT OKSITOSIN DAN HYPNO BREASTFEEDING TERHADAP OPTIMALISASI PRODUKSI ASI PADA IBU NIFAS
}

\author{
${ }^{1}$ Fitriani Ningsih, ${ }^{2}$ Rizki Muji Lestari
}

1) Diploma Tiga Kebidanan, Sekolah Tinggi Ilmu Kesehatan Kota Palangka Raya Provinsi Kalimantan Tengan

\author{
E-mail: feghanz@gmail.com
}

\begin{abstract}
ABSTRAK
Salah satu faktor yang mempengaruhi kelancaran produksi ASI adalah kondisi fisik dan psikologi ibu nifas. Rendahnya kepercayaan diri ibu akan keberhasilan menyusui dapat menurunkan produksi ASI lbu. Berkaitan dengan per-masalahan tersebut di atas sangat perlu dipecahkan dan diselesaikan, salah satunya dengan memberikan intervensi kombinasi antara pijat oksitosin dan Hypno breastfeeding. Hypnobreast-feeding merupakan salah satu persiapan ibu dari segi pikiran (mind) meliputi ketenangan pikiran. Tujuan penelitian ini untuk melihat efektivitas pemberian tindakan pijat oksitosin dan Hypno breastfeeding terhadap Optimalisasi Produksi ASI Pada lbu Nifas. Desain penelitian ini menggunakan desain penelitian Eksperimen semu (Quasy Experiment) dengan rancangan Posttest Only Design with Nonequivalent Groups, menggunakan sampel 30 responden ibu nifas yang ada di ruang Nifas RSUD dr. Doris Sylvanus Kota Palangka Raya. Kelompok ini dibagi menjadi 15 responden sebagai kelompok intervensi dan 15 responden sebagai kelompok kontrol. Pada penelitian ini menggunakan uji statistik Chi-Square. Berdasarkan hasil penelitian didapatkan nilai $p=0,020$ dengan ketentuan nilai $p<0.05$, maka $P$ value $>$ a sehingga dapat disimpulkan bahwa kombinasi antara pijat oksitosin dan Hypno breastfeeding sangat efektif untuk optimalisasi produksi ASI pada ibu Nifas. Dan dari hasil uji statistik didapatkan nilai OR 7,4 (Cl 1,226-45,005) artinya kombinasi antara pijat oksitosin dan Hypno breastfeeding berpeluang 7,4 kali untuk mengoptimalisasi produksi ASI.
\end{abstract}

Kata Kunci: Pijat Oksitosin; Hypno breastfeeding; ASI; Nifas

\section{ABSTRACT}

One of the factors that influence the smooth production of breast milk is the physical and psychological condition of the puerperal mother. Mother's milk. In connection with the problems mentioned above, it is very necessary to be solved and resolved, one of them by providing interventions between oxytocin massage and Hypno breastfeeding. Hypno breastfeeding is one of the preparation of the mother in terms of mind.The purpose of this study was to look at the workings of oxytocin and Hypno breastfeeding therapy on the Optimization of Breast Milk Production in Postpartum Mothers. The design of this study used a quasi-experimental research design (Rapid Experiment) with a design only Posttest Design with Quarter Groups, using a sample of 30 postpartum mothers respondents in the postpartum hospital dr.Doris Sylvanus Palangkaraya City. This group was divided into 15 
respondents as an intervention group and 15 respondents as a control group. In this study using the Chi-Square statistical test.

Based on the results of the study obtained $P$ value $=0.020$ with the provisions of the value of $p<0.05$, then the $P$ value $>$ which can be concluded that the combination of oxytocin massage and Hypno breastfeeding is very effective for optimizing breast milk production in postpartum mothers. And from the statistical test results obtained an OR value of $7.4(\mathrm{Cl}$ 1.222-45.005) meaning that the combination of oxytocin massage and Hypno breastfeeding has a 7.4 chance to optimize milk production.

Keywords: Oxytocin Massage; Hypno breastfeeding; ASI; Postpartum

\section{Pendahuluan}

Salah satu tugas utama ibu pada masa ibu adalah bertanggungjawab dalam memenuhi kebutuhan nutrisi bayi dengan cara menyusui. Menyusui sangat erat kaitannya dengan Air Susu lbu (ASI). Air Susu Ibu merupakan makanan pilihan utama pada bayi, karena waktu lahir bayi memproduksi sedikit amilase saliva atau pankreas, dengan demikian bayi tidak siap mencerna karbohidrat kompleks yang diperoleh dari makanan padat. Selain itu menyusui memberi banyak keuntungan antara lain pemenuhan kebutuhan nutrisi, imunologi dan psikologis. Pemberian air susu ibu (ASI) secara eksklusif telah direkomendasikan oleh World Health Organization (WHO) untuk diberikan sampai umur bayi 6 bulan, namun munculnya berbagai hambatan dalam proses menyusui membuat ibu tidak memberikan ASI eksklusif [1].

Menurut data yang didapat dari World Breastfeeding Trends Initiative (WBTI) pada tahun 2010 hanya 27,5\% ibu di Indonesia yang berhasil memberikan ASI Eksklusif, dari hasil tersebut membuat Indonesia berada di peringkat 49 dari 51 negara yang mendukung pemberian ASI Eksklusif [2]. Cakupan pemberian ASI Eksklusif di Provinsi Kalimantan Tengah menunjukkan prosentase $38,2 \%$, angka tersebut masih belum mencapai target cakupan pemberian ASI eksklusif seperti yang telah ditetapkan oleh Kementerian Kesehatan tahun 2014 yaitu 80 \% [3]. Cakupan ASI Eksklusif kota Palangka Raya selama 5 tahun berturut-turut yaitu tahun 2010 sampai dengan 2016 tidak mengalami peningkatan yang signifikan dan masih berada jauh dibawah target Nasional. Cakupan pemberian ASI Eksklusif pada tahun 2010 yaitu 30,3\%, tahun 2011 yaitu 19,5\%, tahun 2012 yaitu 18,8\%, tahun 2013 yaitu $33,2 \%$, tahun 2014 yaitu 39,3\%, tahun 2015 yaitu $41,9 \%$ dan tahun 2016 yaitu 14,99\% [4].

Peran ibu adalah bertanggungjawab dalam memenuhi kebutuhan nutrisi bagi bayinya. Namun ternyata masih didapatkan kondisi kegagalan menyusui dan hambatan pengeluaran ASI. Kondisi hambatan pengeluaran ASI ini dapat berdampak pada risiko kegagalan tercapainya ASI Eksklusif.

Salah satu faktor yang mempengaruhi kelancaran produksi ASI adalah kondisi fisik 
dan psikologi ibu nifas. Rendahnya kepercayaan diri ibu akan keberhasilan menyusui dapat menurunkan produksi ASI lbu [5]. Berkaitan dengan permasalahan tersebut di atas sangat perlu dipecahkan dan diselesaikan, salah satunya dengan memberikan intervensi kombinasi antara pijat oksitosin dan Hypno breastfeeding.

Hypno breastfeeding merupakan salah satu persiapan ibu dari segi pikiran (mind) meliputi ketenangan pikiran, sehingga ibu percaya diri bahwa dirinya mampu memproduksi ASI sedangkan pijat oksitosin merupakan salah satu solusi untuk mengatasi ketidaklancaran produksi ASI. Pemijatan ini dilakukan pada sepanjang tulang belakang (vertebrae) sampai tulang costae kelimakeenam yang tujuannya untuk merangsang hormon prolaktin dan oksitosin setelah melahirkan. Pijatan ini juga berfungsi untuk meningkatkan hormon oksitosin yang dapat menenangkan ibu, sehingga ASI otomatis keluar [6].

\section{Metode}

Penelitian ini dilakukan dengan menggunakan desain penelitian Eksperimen semu (Quasy Experiment) dengan rancangan Posttest Only Design with Nonequivalent Groups, menggunakan sampel 30 responden ibu nifas yang ada di ruang Nifas RSUD. Dr. Doris Sylvanus Palangka Raya yang terbagi menjadi 15 responden sebagai kelompok intervensi dan 15 responden sebagai kelompok kontrol. Pada penelitian ini sebagai variable independent adalah intervensi kombinasi pijat oksitosin dan Hypno breastfeeding, sedangkan sebagai variabel dependent adalah produksi ASI pada ibu nifas. Pada penelitian ini menggunakan uji statistik Chi-Square dengan menggunakan komputerisasi 


\section{Hasil Penelitian dan Pembahasan}

1. Analisis Univariat

Tabel 1. Karakteristik responden di ruang Nifas RSUD. Dr. Doris Sylvanus Palangka Raya tahun 2019

\begin{tabular}{lcc}
\hline \multicolumn{1}{c}{ Variabel } & F & $\%$ \\
\hline Umur ibu & 23 & 76,7 \\
$20-35$ tahun & 7 & 23,3 \\
$<20$ tahun dan $>35$ tahun & 30 & 100 \\
Total & 21 & 70,0 \\
\hline Paritas & 9 & 30,0 \\
$\geq 2$ & 30 & 100 \\
$<2$ & 17 & 56,7 \\
Total & 13 & 43,3 \\
\hline Frekuensi pemberian ASI & 30 & 100 \\
$\geq 8$ kali & 17 & 56,7 \\
$<8$ kali & 13 & 43,3 \\
Total & 30 & 100 \\
\hline Dukungan keluarga & & 70,0 \\
Mendukung & 21 & 30,0 \\
Tidak mendukung & 9 & 100 \\
Total & 30 & \\
\hline Motivasi & & \\
Tinggi & & \\
Rendah & & \\
Total & & \\
\hline
\end{tabular}

Berdasarkan data di atas karakteristik ibu berdasarkan umur mayoritas pada kelompok umur 20-35 tahun yaitu sebanyak 23 responden (76,7\%); berdasarkan paritas mayoritas pada kelompok $\geq 2$ anak yaitu sebanyak 21 responden $(70 \%)$; berdasarkan frekuensi pemberian ASI mayoritas $\geq 8$ kali yaitu sebanyak 17 responden berdasarkan dukungan keluarga mayoritas keluarga mendukung yaitu sebanyak 17 responden (5,7\%) dan berdasarak motivasi mayoritas maotivasi responden tinggi yaitu sebanyak 21 responden (70\%). 


\section{Analisis Bivariat}

Tabel 2. Hubungan umur dan paritas terhadap Produksi ASI Ibu di ruang Nifas RSUD. Dr. Doris Sylvanus Palangka Raya tahun 2019

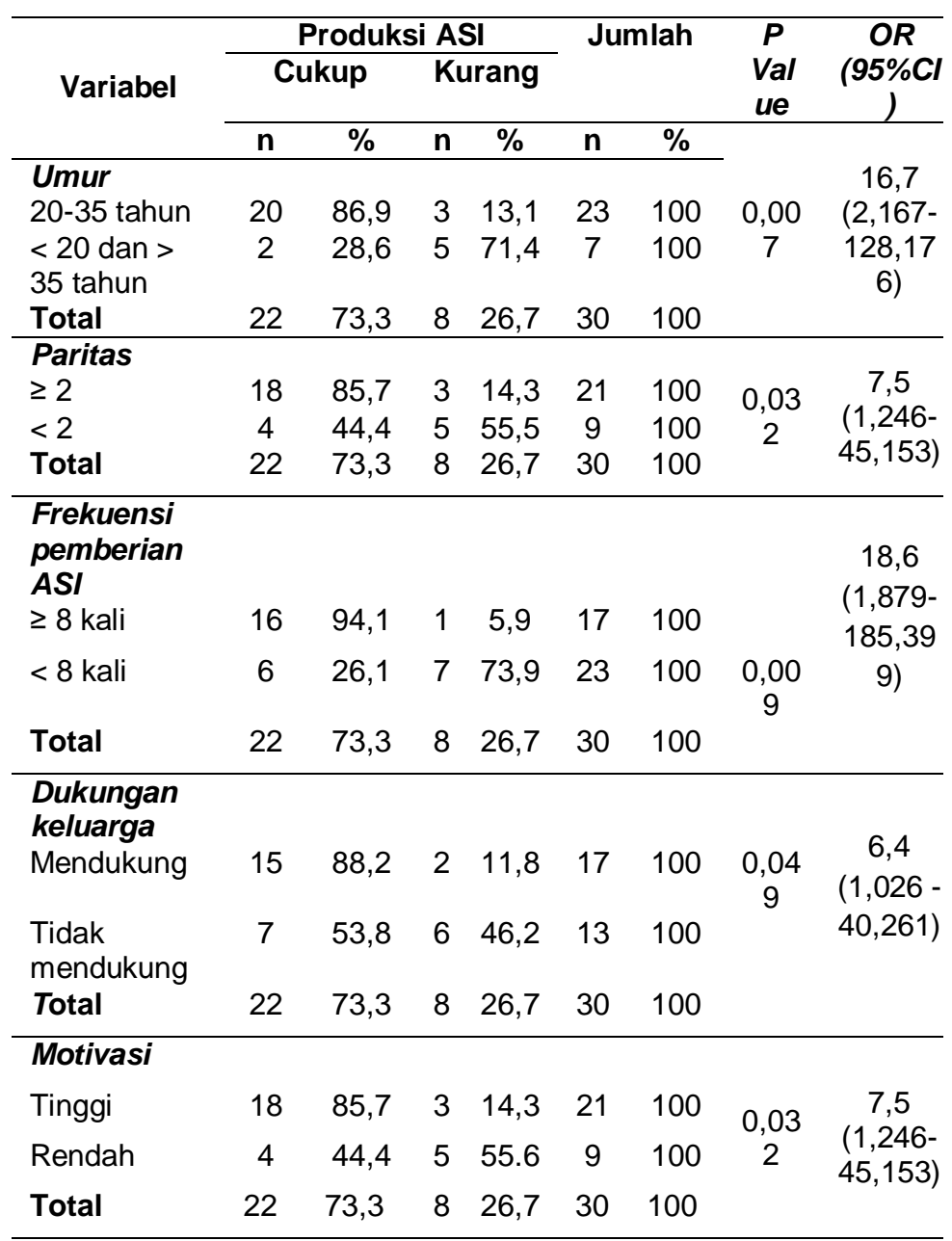

Berdasarkan tabel di atas hasil uji statistik hubungan antara umur dengan produksi ASI diperoleh $P$ value $=0,007$ artinya ada hubungan yang signifikan antara umur ibu nifas dengan produksi ASI. Hasil analisis diperoleh pula nilai $\mathrm{OR}=16,7$ yang berarti bahwa ibu nifas yang berumur $20-35$ tahun mempunyai peluang sebesar 16,7 kali untuk memproduksi ASI dalam kategori cukup dibandingkan ibu nifas yang berumur $<20$ dan $>35$ tahun.
Hasil uji statistik hubungan antara paritas dengan produksi ASI diperoleh $P$ value $=0,032$ artinya ada hubungan yang signifikan antara paritas dengan produksi ASI. Hasil analisis diperoleh pula nilai $\mathrm{OR}=7,5$ yang berarti bahwa ibu nifas yang memiliki paritas $\geq$ 2 mempunyai peluang sebesar 7,5 kali untuk memproduksi ASI dalam kategori cukup dibandingkan ibu nifas yang memiliki paritas < 2. 
Hasil uji statistik hubungan antara frekuensi pemberian ASI dengan produksi ASI diperoleh $\mathrm{p}$ value $=0,009$ artinya ada hubungan yang signifikan antara frekuensi pemberian ASI dengan produksi ASI. Hasil analisis diperoleh pula nilai $\mathrm{OR}=18,6$ yang berarti bahwa ibu nifas yang memiliki frekuensi pemberian $\mathrm{ASI} \geq 8$ kali mempunyai peluang sebesar 18,6 kali untuk memproduksi ASI dalam kategori cukup dibandingkan ibu nifas yang memiliki frekuensi pemberian $\mathrm{ASI}<8$ kali.

Hasil uji statistik hubungan antara dukungan keluarga dengan produksi ASI diperoleh $p$ value $=0,049$ artinya ada hubungan yang signifikan antara dukungan keluarga dengan produksi ASI. Hasil analisis diperoleh pula nilai $\mathrm{OR}=6,4$ yang berarti bahwa ibu nifas yang mendapatkan dukungan keluarga mempunyai peluang sebesar 6,4 kali untuk memproduksi ASI dalam kategori cukup dibandingkan ibu nifas yang tidak mendapatkan dukungan keluarga.

Hasil uji statistik hubungan antara motivasi dengan produksi ASI diperoleh $p$ value $=0,032$ artinya ada hubungan yang signifikan antara motivasi dengan produksi ASI. Hasil analisis diperoleh pula nilai $\mathrm{OR}=$ 7,5 yang berarti bahwa ibu nifas yang memiliki motivasi tinggi mempunyai peluang sebesar 7,5 kali untuk memproduksi ASI dalam kategori cukup dibandingkan ibu nifas yang memiliki motivasi rendah.

Tabel 3. Hasil Uji Normalitas

\begin{tabular}{lccc}
\hline Produksi & \multicolumn{3}{c}{ Shapiro-Wilk } \\
\cline { 2 - 4 } ASI/ & & df & Sig. \\
Kelompok & Statistic & df \\
\hline Intervensi & 0,499 & 15 & 0,000 \\
\hline Kontrol & 0,643 & 15 & 0,000 \\
\hline
\end{tabular}

Dari tabel diatas dapat dilihat bahwa dengan jumlah sampel 30 responden untuk produksi ASI pada kelompok intervensi dan kelompok kontrol didapatkan nilai $p=0,000$ dan 0,000 dengan ketentuan nilai $p>0.05$, maka dapat disimpulkan bahwa data tidak berdistribusi normal. Selanjutnya setelah diketahui bahwa hasil data penelitian tidak berdistribusi normal, maka uji statistik yang digunakan adalah uji Non parametrik yaitu uji Chi-Square karena data berupa data kategorik atau nominal. Adapun hasil dari uji statistik tersebut adalah sebagai berikut:

Tabel 4. Efektifitas Kombinasi Pijat Oksitosin Dan Hypno breastfeeding Terhadap Optimalisasi Produksi Asi Pada Ibu Nifas Di Nifas RSUD. Dr. Doris Sylvanus Palangka Raya tahun 2019

\begin{tabular}{|c|c|c|}
\hline $\begin{array}{l}\text { Produksi } \\
\text { ASI/Kelompok }\end{array}$ & P Value & $\begin{array}{c}\text { OR } \\
(95 \% \mathrm{Cl})\end{array}$ \\
\hline $\begin{array}{l}\text { Kelompok intervensi } \\
\text { Kelompok kontrol }\end{array}$ & 0,020 & $\begin{array}{c}7,4(1,226- \\
45,005)\end{array}$ \\
\hline
\end{tabular}

ketentuan nilai $\mathrm{p}<0.05$, maka $P$ value $>$ a sehingga dapat disimpulkan bahwa kombinasi antara pijat oksitosin dan Hypno breastfeeding sangat efektif untuk optimalisasi produksi ASI pada ibu Nifas. Dan dari hasil uji statistik didapatkan nilai OR 7,4 (Cl 1,226-45,005) artinya kombinasi antara pijat oksitosin dan Hypno breastfeeding berpeluang 7,4 kali untuk mengoptimalisasi produksi ASI.

\section{Pembahasan}

\section{Hubungan umur dengan produksi ASI}

Berdasarkan hasil penelitian antara umur dengan produksi ASI diperoleh $P$ value $=0,007$ 
artinya ada hubungan yang signifikan antara umur ibu nifas dengan produksi ASI. Hasil analisis diperoleh pula nilai $\mathrm{OR}=16,7$ yang berarti bahwa ibu nifas yang berumur 20 - 35 tahun mempunyai peluang sebesar 16,7 kali untuk memproduksi ASI dalam kategori cukup dibandingkan ibu nifas yang berumur $<20$ dan $>35$ tahun. Umur atau usia ibu berpengaruh terhadap produksi ASI. Ibu yang umur nya lebih muda banyak memproduksi ASI dibandingkan dengan ibu yang sudah tua [7]. Bahwa ibu yang lebih muda atau umurnya kurang dari 35 tahun lebih banyak memproduksi ASI dari pada ibu yang lebih tua. Dalam kurun waktu reproduksi sehat dikenal bahwa usia aman untuk kehamilan, persalinan dan menyusui adalah 20-35 tahun. Oleh sebab itu, yang sesuai dengan masa reproduksi sangat baik dan sangat mendukung dalam proses pembentukkan dan produksi ASI, sedangkan umur yang kurang dari 20 tahun dianggapmasih belum matang secara fisik, mental dan psikologi dalam menghadapi kehamilan, persalinan serta pemberian ASI. Umur lebih dari 35 tahun dianggap berbahaya, sebab baik alat reproduksi maupun fisik ibu sudah jauh berkurang dan menurun, selain itu bisa terjadi komplikasi bawaan pada bayi,, komplikasi selama persalinan dan juga dapat mengakibatkan kesulitan pada kehamilan, persalian dan nifas. Umur ibu sangat menetukan kesehatan maternal karena berkaitan dengan kondisi kehamilan, persalinan dan nifas serta cara mengasuh juga menyusui bayinya. Ibu yang berumur kurang dari 20 tahun masih belum matang dan belum siap secara jasmani dan sosial dalam menghadapi kehamilan, persalinan serta dalam membina bayi yang dilahirkan. Pada ibu dengan usia 35 tahun ke atas dimana reproduksi hormon relative berkurang, mengakibatkan proses laktasi menurun, sedangkan pada usia (12-19 tahun) harus dikaji pula secara teliti karena perkembangan fisik, psikologis, maupun sosialnya belum siap sehingga dapat mengganggu keseimbangan psikologi dan dapat mempengaruhi dalam produksi ASI [8].

Hasil penelitian ini sesuai dengan penelitian refensi [9] yang menyatakan bahwa sebanyak 4 responden (8,0\%) mengalami onset laktasi lambat pada umur ibu tidak berisiko yaitu umur 20-30 tahun dan sebanyak 19 responden $(38,0 \%)$ yang mengalami onset laktasi cepat. Umur ibu merupakan merupakan salah satu faktor resiko yang berhubungan dengan kualitas kehamilan atau berkaitan dengan kesiapan ibu dalam reproduksi. Namun, secara kesehatan reproduktif seseorang akan mampu bereproduksi sehat (dalam hal ini hamil, bersalin, nifas) adalah pada usia 20 tahun sampai dengan 35 tahun [10].

\section{Hubungan paritas dengan produksi ASI}

Berdasarkan hasil penelitian antara paritas dengan produksi ASI diperoleh $P$ value $=0,032$ artinya ada hubungan yang signifikan antara paritas dengan produksi ASI. Hasil 
analisis diperoleh pula nilai $\mathrm{OR}=7,5$ yang berarti bahwa ibu nifas yang memiliki paritas $\geq$ 2 mempunyai peluang sebesar 7,5 kali untuk memproduksi ASI dalam kategori cukup dibandingkan ibu nifas yang memiliki paritas < 2. Ibu yang melahirkan anak ke dua san seterusnya produksi ASI lebih banyak dibandingkan dengan kelahiran anak pertama [7]. Paritas adalah jumlah janin dengan berat badan lebih dari atau sama dengan 500 gram yang pernah dilahirkan hidup maupun mati. Seorang ibu dengan hanya karena tidak tahu cara-cara yang sebenarnya dan apabila ibu mendengar ada pengalaman menyusui yang kurang baik yang dialami orang lain, hal ini memungkin ibu ragu untuk memberikan ASI pada bayinya [11]. Menurut penelitian referensi [12] paritas dalam menyusui adalah pengalaman pemberian ASI Eksklusif, menyusui pada anak sebelumnya, kebiasaan menyusui dalam keluarga, serta pengetahuan tentang manfaat ASI berpengaruh terhadap keputusan ibu untuk menyusui atau tidak. Dukungan dokter, bidan atau petugas kesehatan lainnya, juga kerabat dekat sangat dibutuhkan terutama untuk ibu yang pertama kali hamil.

3. Hubungan frekuensi pemberian ASI dengan produksi ASI

Berdasarkan hasil penelitian antara frekuensi pemberian ASI dengan produksi ASI diperoleh $\mathrm{p}$ value $=0,009$ artinya ada hubungan yang signifikan antara frekuensi pemberian ASI dengan produksi ASI. Hasil analisis diperoleh pula nilai $\mathrm{OR}=18,6$ yang berarti bahwa ibu nifas yang memiliki frekuensi pemberian $\mathrm{ASI} \geq 8$ kali mempunyai peluang sebesar 18,6 kali untuk memproduksi ASI dalam kategori cukup dibandingkan ibu nifas yang memiliki frekuensi pemberian $\mathrm{ASI}<8$ kali. Semakin sering bayi menyusui, maka produksi dan pengeluaran ASI akan semakin banyak. Akan tetapi, frekuensi menyusui pada bayi prematur dan cukup bulan berbeda. Menyusui bayi paling sedikit 8 kali per hari pada periode awal setelah melahirkan. Frekuensi penyusunan berkaitan dengan kemampuan stimulasi hormon dalam kelenjar payudara [13].

Hal ini sejalan dengan penelitian referensi [14] menunjukkan bahwa terdapat korelasi antara frekuensi ibu menyusui dengan kelancaran ASI dengan nilai $P$ Value $=0,000$. Bayi sebaiknya disusui setiapkali atau kapan saja bayi membutuhkan, dengan durasi pada tiap payudara \pm 10 menit secara bergantian. Apabila bayi tergolong bayi yang mudah tertidur, ibu harus lebih aktif untuk membangunkannya dengan mengganti posisi menyusui atau bahkan dengan menggelitik kakinya selama disusui agar bayi tetap terjaga. Bila bayi belum kenyang setelah disusui, kosongkan satu payudara dan dapat diberikan payudara lainnya [7]. Selain itu, penelitian referensi [15] juga menyatakan bahwa frekuensi menyusui berhubungan dengan kelancaran produksi $\mathrm{ASI}$ ibu dengan nilai $\mathrm{P}$ Value $=0,019$. Pemberian ASI yang lebih 
sering akan meningkatkan isapan anak pada payudara ibu, hal ini akan merangsang otot polos yang terdapat dalam buah dada untuk berkontraksi yang kemudian merangsang susunan syaraf di sekitarnya dan meneruskan rangsangan ini ke otak. Otak akan memerintahkan kelenjar hypofisis bagian belakang untuk mengeluarkan pituirin lebih banyak, sehingga akan mempengaruhi kuatnya kontraksi otot-otot polos buah dada dan uterus. Kontraksi otot-otot polos pada buah dada berguna untuk pembentukan air susu ibu

\section{Hubungan dukungan keluarga dengan produksi ASI}

Berdasarkan hasil penelitian antara dukungan keluarga dengan produksi ASI diperoleh $p$ value $=0,049$ artinya ada hubungan yang signifikan antara dukungan keluarga dengan produksi ASI. Hasil analisis diperoleh pula nilai $\mathrm{OR}=6,4$ yang berarti bahwa ibu nifas yang mendapatkan dukungan keluarga mempunyai peluang sebesar 6,4 kali untuk memproduksi ASI dalam kategori cukup dibandingkan ibu nifas yang tidak mendapatkan dukungan keluarga.

Menyusui memerlukan kondisi emosional yang stabil, mengingat faktor psikologis ibu sangat memengaruhi produksi ASI. Dari semua dukungan bagi ibu menyusui dukungan suami dan keluarga paling berarti bagi ibu. Suami dapat berperan aktif dalam keberhasilan ASI eksklusif karena suami akan turut menentukan kelancaran refleks pengeluaran ASI (milk let down reflex) yang sangat dipengaruhi oleh keadaan emosi atau perasaan ibu. Dukungan suami atau keluarga merupakan salah satu faktor penting dalam memicu refleks oksitosin sehingga produksi ASI meningkat. Hal ini sejalan dengan penelitian referensi [16] yang menyatakan bahwa dukungan keluarga sangat mempengaruhi produksi $\mathrm{ASI}$ dengan nila $\mathrm{P}$ Value 0,000. Dukungan keluarga adalah dukungan untuk memotivasi ibu memberikan ASI saja kepada bayinya sampai usia 6 bulan, memberikan dukungan psikologis kepada ibu dan mempersiapkan nutrisi yang seimbang kepada ibu. Dukungan dari keluarga mempunyai peran yang sangat besar dalam meyakinkan ibu untuk berperilaku menyusui.

\section{Hubungan motivasi dengan produksi} ASI

Berdasarkan hasil penelitian antara motivasi dengan produksi ASI diperoleh $p$ value $=0,032$ artinya ada hubungan yang signifikan antara motivasi dengan produksi ASI. Hasil analisis diperoleh pula nilai $\mathrm{OR}=$ 7,5 yang berarti bahwa ibu nifas yang memiliki motivasi tinggi mempunyai peluang sebesar 7,5 kali untuk memproduksi ASI dalam kategori cukup dibandingkan ibu nifas yang memiliki motivasi rendah.

Keberhasilan menyusui didukung oleh persiapan psikologis yang dipersiapkan sejak masa kehamilan. Keinginan dan motvasi yang kuat untuk menyusui bayinya akan mendorong ibu untuk selalu berusaha menyusui bayinya 
dalam kondisi apapun. Dengan motivasi yang kuat. Seorang ibu tidak akan mudah menyerah meskipun ada masalah dalam proses menyusui bayinya. Dengan demikian maka ibu akan selalu menyusui bayinya sehingga rangsangan pada puting akan mempengaruhi let down refleks sehingga aliran ASI menjadi lancar [6]. Hal ini sejalan dengan penelitian referensi [17] yang menyatakan bahwa ada hubungan antara motivasi terhadap produksi ASI dengan nilai $P$ Value 0,01 . Motivasi seorang ibu sangat menentukan di dalam pemberian ASI eksklusif selama 6 bulan. Motivasi yang berarti dorongan dari dalam diri manusia untuk bertindak atau berperilaku. Pengertian motivasi tidak terlepas dari kata kebutuhan atau needs atau want. Kebutuhan adalah suatu potensi dalam diri manusia yang perlu ditanggapi atau direspon. Tanggapan terhadap kebutuhan tersebut diwujudkan dalam bentuk tindakan untuk pemenuhan kebutuhan tersebut, dan hasilnya adalah orang bersangkutan merasa atau menjadi puas [18].

\section{Efektifitas Kombinasi Pijat Oksitosin}

\section{Dan Hypno breastfeeding Terhadap Optimalisasi Produksi Asi}

Berdasarkan hasil penelitian didapatkan nilai $p=0,020$ dengan ketentuan nilai $p<0.05$, sehingga dapat disimpulkan bahwa kombinasi antara pijat oksitosin dan Hypno breastfeeding sangat efektif untuk optimalisasi produksi ASI pada ibu Nifas. Dan dari hasil uji statistik didapatkan nilai OR 7,4 (Cl 1,226-45,005) artinya kombinasi antara pijat oksitosin dan
Hypno breastfeeding berpeluang 7,4 kali untuk mengoptimalisasi produksi ASI.

Salah satu keluhan yang sering dialami ibu nifas minggu pertama adalah produksi ASI yang kurang dan ini salah satu faktor penyebab kegagalan ASI eksklusif. Produksi ASI dipengaruhi oleh banyak faktor, terutama faktor psikologi dan fisiologi (hormonal), yang memengaruhi sintesis dan sekresi, serta pengeluaran air susu. Peningkatan produksi ASI salah satunya dapat dilakukan dengan Hypno breastfeeding dan pijat oksitosin. Hypno breastfeeding adalah teknik relaksasi untuk membantu kelancaran proses menyusui. Caranya memasukkan kalimat-kalimat afirmasi yang positif yang membantu proses menyusui di saat ibu dalam keadaan rileks atau sangat berkonsentrasi pada suatu hal. Definisi hynosis sendiri adalah suatu kondisi nirsadar yang terjadi secara alami, dimana seseorang mampu menghayati pikiran dan sugesti tertentu untuk mencapai perubahan psikologis, fisik maupun spiritual yang diinginkan. Hypnosis sendiri terjadi otomatis kapanpun seseorang dalam keadaan rileks yang dalam atau berkonsentrasi penuh. Sedangkan pijat oksitosin merupakan stimulasi yang dapat diberikan untuk merangsang pengeluaran ASI. Sebagaimana ditulis dalam referensi [19] bahwa perawatan pijat oksitosin berulang bisa meningkatkan produksi hormon oksitosin. Melalui pijatan pada tulang belakang,ibu akan merasa tenang, rileks, mengurangirasa nyeri, merileksasi ketegangan dan menghilangkan 
stress, sehingga dengan begitu hormon oksitosin keluar dan ASI pun cepat keluar. Pijat oksitosin dilakukan dengan pemijatan tulang belakang sampai tulang costae ke 5-6 melebar ke scapula yang akan mempercepat kerja syaraf parasimpatis untuk menyampaikan perintah ke otak sehingga pengeluaran hormon oksitosin meningkat [20].

Hasil penelitian ini pun sejalan dengan penelitian referensi [21] yang menyatakan bahwa Hypno breastfeeding dapat meningkatkan produksi $\mathrm{ASI}$ dengan nilai $\mathrm{P}$ value 0,000 , pada kelompok yang diberikan intervensi nilai mean sebelum diberikan Hypno breastfeeding sebesar $210 \mathrm{cc}$ dan nilai mean sesudah diberikan Hypno breastfeeding sebesar $255 \mathrm{cc}$. Hal ini munenunjukkan bahwa terdapat peningkatan produksi ASI pada ibu nifas setelah diberikan Hypno breastfeeding. Pelaksanaan Hypno breastfeeding dengan mendengarkan suara secara berulangkali oleh ibu sehingga tertanam kuat dalam pikiran bawah sadar ibu dan setiap saat selalu membangkitkan motivasi dan kepercayaan diri ibu untuk menyusui. Tingkat kepercayaan diri menyusui ibu yang tinggi akan membentuk pola pemberian ASI eksklusif sehingga meskipun ketika terkendala ibu bekerja, ibu akan berupaya untuk memberikan ASI dengan sering menyusui bayi saat bersama bayi dan melakukan pemerahan ASI saat ibu bekerja. Hypno breastfeeding akan membuat membuat seseorang dalam kondisi trance atau membawa alam pikiran dari conscious mind ke subconscious mind. Dalam penelitian ini, tahap rileksasi dicapai melalui tehnik relaksasi otot, relaksasi nafas dan relaksasi pikiran. Semua tehnik relaksasi didapatkan dengan mengikuti instruksi terapis/penghipnotis yang suaranya telah terekam dengan iringan alunan musik yang lembut sehingga ibu akan merasa lebih rileks.

Selain itu, pijat ositosin merupakan cara lain untuk meningkatkam produksi $\mathrm{ASI}$, hal ini sejalan dengan penelitian referensi [22] yang menyatakan bahwa pijat oksitosin sangat berhubungan erat dengan produksi ASI ( $P$ Value 0,001). Pijat oksitoksin bermanfaat dalam mempengaruhi hipofise untuk mengeluarkan hormon prolaktin dan oksitosin, hormon prolaktin mempengaruhi jumlah produksi ASI dan hormon oksitosin mempengaruhi pengeluaran ASI. Penelitian referensi [23] juga menyatakan bahwa terdapat hubungan signifikan antara pijat oksitosin dengan kelancaran produksi ASI dengan nilai $P$ Value 0,003 . Pemijatan oksitosin dapat dilakukan dengan cara pijat ibu pada bagian tengkuk dan punggunguntuk memberikan rasa nyaman sehingga dapat membantu dalam pengeluaran ASI. Pijat oksitosin juga berfungsi untuk mengeluarkan endorfin merupakan senyawa yang menenangkan. Dalam keadaan tenang seperti inilah ibu nifas yang sedang menyusui mampu mempertahankan produksi ASI yang mencukupi bagi bayinya. 
Pada penelitian ini, upaya yang dilakukan untuk membantu meningkatkan produksi ASI dengan memberikan tindakan kombinasi Hypno breastfeeding dan pijat oksitosin kepada ibu nifas. Cara ini sangat efektif untuk meningkatkan produksi ASI dengan dibuktikan melalui hasil uji Chi-Square didapatkan nilai $p$ $=0,020$ dengan ketentuan nilai $p<0.05$, sehingga dapat disimpulkan bahwa kombinasi antara pijat oksitosin dan Hypno breastfeeding sangat efektif untuk optimalisasi produksi ASI pada ibu Nifas. Dan dari hasil uji statistik didapatkan nilai OR 7,4 (Cl 1,226-45,005) artinya kombinasi antara pijat oksitosin dan Hypno breastfeeding berpeluang 7,4 kali untuk mengoptimalisasi produksi ASI.

\section{Kesimpulan}

Kombinasi antara pijat oksitosin dan Hypno breastfeeding sangat efektif untuk optimalisasi produksi ASI pada ibu Nifas dengan dibuktikan melalui hasil uji Chi-Square didapatkan nilai $p=0,020$ dengan ketentuan nilai $p<0.05$, sehingga dapat disimpulkan bahwa kombinasi antara pijat oksitosin dan Hypno breastfeeding sangat efektif untuk optimalisasi produksi ASI pada ibu Nifas. Dan dari hasil uji statistik didapatkan nilai OR 7,4 (Cl 1,226-45,005) artinya kombinasi antara pijat oksitosin dan Hypno breastfeeding berpeluang 7,4 kali untuk mengoptimalisasi produksi ASI

\section{Daftar Pustaka}

1. Clifford, J., \& Mcintyre, E. (2014). Who Supports Breastfeeding. Breastfeeding Review, 16(2), 9.

2. Kemenkes, R. I. (2015). Pusdatin (Pusat Data Dan Informasi Kementrian Kesehatan Ri). Kementrian Kesehatan Republik Indonesia.

3. Data, P., \& Ri, I. K. K. (2014). Situasi Dan Analisis Asi Eksklusif. Jakarta: Kementerian Kesehatan Ri.

4. Raya, D. K. K. P. (2017). Profil Kesehatan Kota Palangka Raya Tahun 2016. Dinas Kesehatan Kota Palangka Raya. Palangka Raya.

5. Aprillia, Yesie. (2010). Hipnostetri, Rileks, Nyaman, Dan Aman Saat Hamil Dan Melahirkan. Jakarta : Gagas Media

6. Roesli, Utami. (2013). Inisiasi Menyusu Dini Plus Asi Eksklusif. Pustaka Bunda.Jakarta

7. Soetjiningsih., 2012. Asi Petunjuk Tenaga Kesehatan. Jakarta. Egc

8. Mursyida. 2013. Hubungan Umur lbu dan Paritas dengan Pemberian ASI Eksklusif pada Bayi Berusia 0-6 bulan di Puskesmas Pembina Palembang. Dipublikasikan untuk Poltekkes Kemenkes Palembang, Jurusan Kebidanan

9. Novitasari, H., \& Mawarti, R. (2015). Hubungan Umur Ibu Dengan Onset Laktasi Pada lbu Postpartum Di Rumah Sakit Pku Muhammadiyah 
Yoyakarta(Doctoral Dissertation,

Stikes'aisyiyah Yogyakarta).

10. Khoiria, U. N., \& Mufdlilah, M. (2015). Hubungan Sikap Suami dengan Keberhasilan ASI Eksklusif Di Wilayah Puskesmas Kasihan II Bantul Tahun 2014(Doctoral dissertation,

STIKES'Aisyiyah Yogyakarta).

11. Proverawati, A., \& Rahmawati, E. (2010). Kapita selekta ASI dan menyusui. Yogyakarta: Nuha Medika, 9, 13-17.

12. Arini, H. (2012). Hubungan Umur Dan Tingkat Pendidikan Terhadap Pemberian Asi Eksklusif. Diakses Dari Http://Aperlindraha. Wordpress. Com Pada Tanggal, 14.

13. Rukiyah, Dkk, 2011. Asuhan Kebidanan lii Nifas. Jakarta : Trans Info Media.

14. Sulistiyah. (2016). Hubungan Antara Frekuensi lbu Menyusui Pada Bayi 0-6 Bulan Dengan Kelancaran Asi (Studi Di Puskesmas Bululawang Kabupaten Malang)

15. Anggraini, H., \& Devi, I. P. (2018). Hubungan Inisiasi Menyusu Dini (Imd) Dengan Kecukupan Produksi Air Susu Ibu (Asi) Pada lbu Di Bpm Mastuti Amd. Keb Kecamatan Pardasuka Kabupaten Pringsewu Tahun 2017. Jurnal Kebidanan Malahayati, 4(1).

16. Alwan, L. I., Ratnasari, R., \& Suharti, S. (2018). Asuhan Kebidanan Continuity Of Care Pada Ny M Masa Hamil Sampai
Dengan Keluarga Berencana Di Bpm Muryati Sst. Keb Sukorejo Ponorogo. Health Sciences Journal, 2(2), 104-123.

17. Fatmawati,L.A.I. (2016) Hubungan Dukungan Suami Dengan Sikap Dan Motivasi Ibu Dalam Pemberian Asi Eksklusif Di Wilayah Kerja Puskesmas Danurejan I Kota Yogyakarta

18. Notoatmodjo, S. (2014). Ilmu Perilaku Kesehatan Penerbit Pt Rineka Cipta

19. Lund, I., Yu, L. C., Uvnas-Moberg, K., Wang, J., Yu, C., Kurosawa, M., ... \& Lundeberg, T. (2002). Repeated massage-like stimulation induces longterm effects on nociception: contribution of oxytocinergic mechanisms. European Journal of Neuroscience, 16(2), 330-338.

20. Desmawati. 2013. Penentu Kecepatan Pengeluaran Asi Setelah Sc. Jurnal Kesehatan Masyarakat Nasional. Vol.7. No.8. Maret 2013

21. Rahmawati, A., \& Prayogi, B. (2017). Hypnobreastfeeding untuk Meningkatkan Produksi Asi pada Ibu Menyusui Yang Bekerja. Research Report, 48-53.

22. Meihartati, T. (2016). Hubungan Pijat Oksitosin Terhadap Kelancaran Produksi Asi lbu Post Partum. Jurnal Kebidan an Dan Keperawatan Aisyiyah, 12(2), 193197.

23. Albertina, M. (2017). Hubungan Pijat Oksitosin Dengan Kelancaran Produksi Asi Pada lbu Post Partum Seksio Sesarea 
Hari Ke 2-3. Husada Mahakam, 3(9), 452-

458. 